\title{
PENGARUH LABELLING NEGATIF TERHADAP KENAKALAN REMAJA
}

\author{
${ }^{1}$ Asiyah Jamilah, ${ }^{2}$ Aista Wisnu Putra \\ 12 Fakultas Hukum Universitas Diponegoro, Indonesia \\ E-mail: jamilahasiyah@gmail.com, aistawisnuputra@gmail.com
}

\begin{abstract}
Teenagers are one of the groups that are very vulnerable to be swept along, they are looking for identity and lifestyle that is most suitable for him. It is not uncommon to cause mistakes and the mistakes they do often cause parents concerns and feelings that are uncomfortable for their environment. These mistakes are what are often referred to as juvenile delinquency. Juvenile delinquency is also known as deviant behavior, namely by the participation of a teenager in illegal behavior. This then reaps the response of the public that these behaviors should not be done by adolescents so that it gives rise to stigma/labels against these adolescents. The purpose of this study is to provide an explanation of the factors underlying the occurrence of juvenile delinquency and provide an overview of the influence of community stigma/labels on juvenile delinquency. the approach used in this paper is qualitative. By using a qualitative approach, it is possible to obtain data especially on stigma or labels, and their effects on juvenile delinquency. The results of the study are that two factors are underlying juvenile delinquency, namely factors originating from the external and factors originating from the internal. Then the label given to a person can influence his behavior, which most of the application of negative labels and stigma (such as criminal), increases deviant behavior and becomes a selfconcept.
\end{abstract}

Keywords:

labelling, teenager, juvenile delinquency 


\begin{abstract}
Abstrak
Remaja adalah salah satu kelompok yang sangat rentan ikut terbawa arus, mereka sedang dalam fase pencarian jati diri dan jalan hidup yang paling cocok bagi mereka. Yang mana hal ini tidak jarang menimbulkan kesalahan dan kesalahan yang diperbuatnya tidak jarang menyebabkan kekhawatiran orangtua serta menimbulkan perasaan yang tidak nyaman bagi lingkungan mereka. Kesalahan-kesalahan ini lah yang sering disebut dengan istilah kenakalan remaja. Kenakalan remaja dikenal juga sebagai penyimpangan perilaku yaitu dengan berpartisipasinya seorang remaja dalam perilaku ilegal. Hal inilah kemudian menuai tanggapan masyarakat bahwa perilaku-perilaku tersebut tidak seharusnya diperbuat oleh remaja sehingga memunculkan stigma/label terhadap remaja tersebut. Adapun penelitian ini memiliki tujuan untuk memberikan penjelasan mengenai faktor-faktor yang melatar belakangi terjadinya kenakalan remaja serta memberi gambaran tentang pengaruh stigma/ label masyarakat terhadap kenakalan remaja. pendekatan yang digunakan dalam tulisan ini adalah pendekatan kualitatif. Dengan menggunakan pendekatan kualitatif, dimungkinkan untuk mendapatkan data terutama mengenai stigma atau label serta pengaruhnya pada kenakalan remaja. Hasil dari penelitian yakni terdapat dua faktor yang melatar belakangi kenakalan remaja, yaitu faktor yang berasal dari eksternal dan faktor yang berasal dari internal. Kemudian label yang diberikan kepada seseorang dapat mempengaruhi perilakunya, yang mana sebagian besar penerapan label dan stigma yang negatif (seperti kriminal), meningkatkan perilaku yang menyimpang dan menjadi suatu konsep diri.
\end{abstract}

Kata-kata Kunci:

label, remaja, kenakalan remaja 


\section{Pendahuluan}

Masa remaja adalah masa peralihan dari kanak-kanak ke dewasa. Sebagaimana pendapat para ahli pendidikan bahwa remaja adalah mereka yang berusia antara 13 tahun sampai dengan 18 tahun. Mereka sudah tidak lagi dapat dikatakan sebagai kanak-kanak, tetapi masih belum cukup matang untuk dapat dikatakan dewasa. ${ }^{1}$ Remaja adalah salah satu golongan yang sangat rentan ikut terbawa arus pergaulan ${ }^{2}$ karena mereka sedang mencari pola hidup yang paling sesuai baginya dan inipun sering dilakukan melalui metode coba-coba hingga menyebabkan terjadi banyak kesalahan. Kesalahan yang dilakukannya sering menimbulkan kekhawatiran serta perasaan tidak menyenangkan bagi lingkungan dan orangtuanya. Tidak jarang kesalahan yang diperbuat para remaja hanya akan menyenangkan teman-temannya saja, hal demikian dikarenakan mereka semua memang sama-sama masih dalam tahap pencarian identitas/jati diri. Kesalahankesalahan inilah yang kemudian dikenal sebagai kenakalan remaja. ${ }^{3}$

Saat ini kenakalan remaja/Juvenile delinquency merupakan hal yang perlu mendapat perhatian lebih. Kenakalan remaja merupakan perbuatanperbuatan yang melanggar norma, aturan atau hukum dalam masyarakat yang dilakukan pada usia remaja atau juga dikenal sebagai penyimpangan perilaku dengan cara turut berpartisipasinya seorang remaja dalam tindakan ilegal. ${ }^{4}$ Ada beberapa bentuk kenakalan yang sering dilakukan oleh remaja yakni membolos sekolah, melawan guru, tawuran antar pelajar, sex bebas, balap liar, mencuri, berjudi, hingga mengonsumsi narkotika. Hal inilah kemudian menuai tanggapan masyarakat bahwa perilakuperilaku tersebut tidak seharusnya diperbuat oleh remaja sehingga memunculkan stigma atau label terhadap remaja tersebut.

Labelling adalah proses memberi stigma/label kepada seseorang. Label menurut $A$ Handbook for The Study of MentalHealth, yakni sebuah definisi yang ketika diberikan kepada seseorang, maka akan menjadi

1 Iis Susanti, PambudiHandoyo, Prilaku Menyimpang DikalanganRemaja Pada Masyarakat Karangmojo Plandaan Jombang. Paradigma, Vol. 3 No. 2 (2015): hlm. 2.

2 Nazari Ayu, Khairulyadi, Pengaruh Siigma Terhadap Perubahan Prilaku Remaja (Studi Terhadap StigmaNegatif Remaja Mukim Kongsi Gampong KutaBarat Kota Sabang). Jurnal Ilmiah Mahasiswa Fisip Unsyiah, Vol. 4 No. 1 (Februari 2017): hlm. 234.

3 Dadan Sumarra, SahadiHumaedi, \& Meilany Budiarti Santoso, "Kenakalan Remaja Dan Penanganannya”. Jurnal Penelitian \&Ppm Vol 4, No. 2 (Juli 2017): hlm. 346.

4 Yustika TriDewi, Meilany Budiarti S, Sahadi Humedi \& Budhi Wibhawa, "Faktor Penyebab Tergabungnya Remaja Kota Bandung Dalam Komunitas Kenakalan Remeja". Share: SocialWork Jurnal Vol. 7 No. 1 (Juli 2017): hlm. 14. 
identitas diri orang itu, serta menjelaskan seperti apakah tipe orang tersebut. Dengan pemberian label pada diri seseorang, orang lain akan cenderung menilai dia bukan pada perilakunya satu persatu akan tetapi secara keseluruhan kepribadiannya dinilai berdasarkan label tersebut.

Labelling theory bisa juga dikatakan sebagai teori reaksi sosial. Teori ini mulanya sangat terinspirasi oleh teori interaksi simbolik dari George Herbert Mead dalam bukunya Mind, Self, and Society (1934), yang hanya diterapkan dalam dunia orang-orang yang menyimpang (devians). Menurut teori komunikasi simbolik, orang belajar memainkan peran yang berbeda dan memperoleh identitas untuk peran itu, belajar untuk terlibat dalam kegiatan yang menunjukkan siapa mereka, dan menentukan situasi di mana mereka masuk. Perilaku mereka terjadi dalam konteks sosial, pengertian, dan interpretasi situasi.

Teori penjulukan hanya mengatakan dua hal. Pertama, orang berperilaku normal atau tidak normal, tidak menyimpang atau menyimpang tergantung pada bagaimana orang lain menilai mereka. Penilaian ini sudah ditentukan oleh klasifikasi yang terhubung dengan pemikiran orang lain. Apa pun yang tidak dianggap masuk kategori yang baku (disebut residual) sebagai standar oleh komunitas secara otomatis ditetapkan sebagai menyimpang (Devian).

Kedua, dari waktu ke waktu penilaiannya berubah sehingga orang yang dinyatakan sakit hari ini dapat dinyatakan sehat (dengan gejala yang sama) beberapa tahun kemudian, atau sebaliknya. Jika seseorang diberi julukan yang mengarah pada kejahatan atau perilaku kriminal, orang itu dapat "berhati-hati" untuk melihat sisi negatifnya (seperti orang yang dicap nakal, kriminal, dan lain sebagainya). Teori penamaan/ penjulukan lebih berfokus pada pemahaman kenakalan remaja, karena ini terjadi setiap kali remaja mencoba untuk membentuk identitas mereka.

Menurut Edwin M. Lemert, seseorang berbuat hal yang menyimpang karena suatu proses pelabelan atau penggunaan nama julukan, cap, label, dan merek yang diberikan komunitas/masyarakat kepada individu. Pertama-tama, seseorang melakukan penyimpangan, yang Lemert namakan dengan penyimpangan primer/utama (primary deviation). Pemberian cap atau label sebagai pencuri, penipu, pemerkosa, penjahat dan lain-lain itu karena dilakukannya perbuatan menyimpang seperti pencurian, penipuan, pelanggaran seksual, dan sebagainya. Sebagai tanggapan untuk melabeli orang lain, penyimpang utama lalu menganggap dirinya adalah penyimpang dan mengulangi tindakan yang menyimpang dan melakukan penyim- 
pangan sekunder (secondary deviation) hingga ia mulai mengadopsi gaya hidup yang menyimpang (deviant life style) yang mengarah pada perilaku menyimpang. 5

Ada pemikiran dasar dalam teori pelabelan, dimana pemikirannya adalah bahwa seseorang disebut sebagai seseorang yang berbeda dan bagaimana seseorang diperlakukan yang berbeda dan menjadi berbeda. Penerapan pemikiran ini kurang lebih seperti "seorang anak yang dikatakan susah diatur, akan susah diatur", atau aplikasi lain seperti "anak-anak yang disebut bodoh dan bagaimana anak-anak bodoh diperlakukan sebagai orang bodoh". Ini merujuk pada premis dasar bahwa ketika memberi label pada seseorang, orang cenderung memperlakukan orang tersebut sesuai dengan label yang diberikan, sehingga orang tersebut cenderung mengikuti label yang diberikan kepadanya. ${ }^{6}$

Teori pelabelan berkaitan dengan masalah yang muncul pada lingkungan sosial dipakai untuk mendefinisikan atau melambangkan individu sebagai menyimpang. Hal ini menimbulkan pertanyaan tentang bagaimana pelabelan menyimpang dikenakan pada individu. Bagaimanapun, perilaku menyimpang adalah umum dan seringkali tidak mengarah pada pelabelan. ${ }^{7}$ Misalnya, kenakalan remaja sering tidak dianggap secara khusus menyimpang oleh mereka yang menyaksikan perilaku seperti itu (remaja lainnya), dan dengan demikian sering tidak menyebabkan reaksi khusus oleh lingkungan sosial. Reaksi semacam itu hanya terjadi ketika ada audiensi sosial yang menyebut perilaku (dan individu) sebagai penyimpangan atau tindak kriminal, dalam kasus pelabelan kriminal.

Adapun masalah-masalah yang perlu diuraikan dalam penelitian ini yakni Pertama, Apa faktor-faktor yang melatar belakangi terjadinya kenakalan remaja? dan Kedua, Bagaimana pengaruh stigma/label masyarakat terhadap kenakalan remaja?. Kemudian penelitian ini memiliki tujuan untuk memberikan penjelasan terkait dengan faktor-faktor yang melatar belakangi terjadinya kenakalan remaja serta memberi gambaran tentang pengaruh stigma/label masyarakat terhadap kenakalan remaja.

Untuk menyusun tulisan maka pendekatan yang digunakan adalah pendekatan kualitatif. Pemilihan penggunaan pendekatan kualitatif berda-

5 Kamanto Sunarto, PengantarSosiologi, (Jakarta: Lembaga penerbit FakultasEkonomi UI, 2004), hlm. 179.

${ }^{6}$ NazariAyu, Khairulyadi, hlm. 236.

7 Becker, H. S, Outsiders: Studies in thesociology of deviance. (New York: FreePress, 1963), hlm. 32. 
sarkan kepada kelebihan pendekatan ini dalam pengambilan data.. Dengan menggunakan pendekatan kualitatif, memungkinkan untuk mendapatkan data terutama mengenai stigma atau label serta pengaruhnya pada kenakalan remaja. Berdasarkan hasil diskusi, kesimpulan deduktif disusun sebagai jawaban untuk masalah yang diteliti, yaitu, kesimpulan umum tentang masalah tertentu.

\section{Hasil dan Pembahasan}

\section{Kenakalan Remaja Serta Faktor-Faktor Penyebabnya}

Kenakalan adalah masalah sosial yang tidak jarang terjadi dalam kehidupan sehari-hari terlepas dari status sosial orang yang melakukannya. Kata kenakalan adalah istilah yang terkenal dalam masyarakat. Kenakalan adalah salah satu perilaku menyimpang atau tindakan negatif. ${ }^{9}$ Kenakalan remaja dapat juga disebut menggunakan istilah juvenile delinquent. Juvenile berasal dari bahasa latin "juvenilis", yang berarti anak-anak, anak muda, ciri karakteristik pada masa muda, dan sifat-sifat khas pada masa remaja. Sedangkan delinquent, dalam bahasa latin "delinquere", berarti terabaikan, mengabaikan, yang kemudian diperluas artinya menjadi jahat, nakal, anti sosial, kriminal, pelanggar aturan, pembuat ribut, pengacau, penteror, tidak dapat diperbaiki lagi, durjana, dursila dan lain sebagainya. Kenakalan remaja mencakup semua perilaku yang menyimpang dari aturan hukum yang dilakukan remaja. Perilaku tersebut tidak hanya akan merugikan dirinya sendiri akan tetapi juga merugikan orang lain di sekitarnya. Kartini Kartono seorang ilmuwan sosiologi membuat definisi kenakalan remaja atau yang dikenal dalam bahasa Inggris dengan istilah juvenile delinquency merupakan karakteristik dari gejala patologis sosial pada remaja yang disebabkan oleh bentuk pengabaian sosial. Mereka mengembangkan bentuk perilaku yang menyimpang sebagai akibatnya. ${ }^{10}$

Santrock juga mendefinisikan, kenakalan remaja adalah kumpulan dari macam-macam perilaku yang berbeda mulai dari perilaku yang secara sosial tidak dapat diterima hingga pada tindak kriminal. Mussen kemudian

${ }^{8}$ Rio Tutrianto, "Munculnya Wilayah Kejahatan di Perkotaan (Studi Pada Kota Pekanbaru)”. Jurnal Kriminologilndonesia Vol. 14 No. 1 (Mei 2018): hlm. 17

${ }^{9}$ AliAkhbar Rafsanjani Hutagalung, "Kajian Kriminologis Perilaku Nakal Anak Jalanan (Studi Kasus Di Yayasan Setara Semarang)". (Skripsi Universitas Negri Semarang, 2017), hlm. 43.

10 Kartini Kartono, Patologi Sosial2: Kenakalan Anak (Jakarta: Rajagrafindo Persada, 2010), hlm. 6. 
mengungkapkan bahwa kenakalan remaja merupakan kejahatan atau pelanggaran hukum yang dilakukan oleh seorang remaja, biasanya berusia 16 hingga 18 tahun dan jika tindakan tersebut dilakukan oleh orang dewasa, maka hukum dapat diberlakukan. ${ }^{11}$

Tindakan remaja yang masih mencari identitas dapat mengganggu ketenangan orang lain. Pelanggar ringan yang mengganggu perdamaian di lingkungan sekitar mereka seperti sering pergi keluar di malam hari dan menghabiskan waktu hanya untuk hura-hura, mabuk-mabukan, mengonsumsi obat terlarang, berkelahi, bermain judi dan lain sebagainya yang tidak hanya membahayakan mereka sendiri, tetapi juga keluarga mereka, dan orang lain di sekitar mereka. Hal demikian tentu saja tidak lepas dari latar belakang yang mempengaruhinya.

Adapun faktor pendorong remaja/anak yang berbuat nakal pasti tidak sama dengan orang dewasa yang melakukan kejahatan. Menemukan informasi latar belakang atau penyebab anak-anak berbuat nakal sebagai bagian dari bidang kriminologi dapat sangat membantu dalam memperoleh informasi tentang apa yang harus dilakukan dengan anak-anak yang telah melakukan kenakalan. Hal tersebut berarti bahwa berbicara tentang kenakalan remaja terkait erat dengan faktor yang memotivasi atau latar belakang sehingga anak dapat melakukan kejahatan dan akhirnya dapat memutuskan apa yang dibutuhkan anak untuk merespons kesalahan mereka. ${ }^{12}$ Adapun faktor-faktor tersebut dapat dikategorikan menjadi dua bagian, yakni faktor internal dan faktor eksternal.

Pertama, Faktor Internal: Pertama, Krisis identitas. Perubahan biologis dan sosial pada masa remaja memungkinkan dua jenis integrasi. Pertama, terbentuknya kemantapan dalam bertindak di hidupnya. Kedua, mencapai pengenalan karakter. Kenakalan remaja terjadi karena anak muda tidak mencapai periode integrasi kedua. Kedua, Kontrol diri yang tidak kuat. Remaja yang tidak dapat mempelajari perilaku yang tidak dapat diterima dan membedakannya akan tertarik pada perilaku "nakal". Demikian pula bagi mereka yang sudah tahu perbedaan antara dua perilaku ini, tetapi tidak dapat mengembangkan kontrol diri untuk bertindak berdasarkan pengetahuan mereka.

11 Rudi Lestriono, "Tinjauan Kriminologis Terhadap Kenakalan Remaja Di Kabupaten Luwu Timur", (Skripsi Universitas Hasanuddin, 2013), hlm. 23.

12 Nashriana, PerlindunganHukum Pidana Bagi Anak DiIndonesia (Jakarta : Rajawali Pers, 2012),hlm. 35. 
Kedua, Faktor Eksternal :

Pertama, Kurangnya perhatian serta kurangnya kasih sayang dari orang tua. Keluarga adalah unit sosial paling kecil yang merupakan dasar utama terhadap perkembangan anak. Lingkungan sekitar serta sekolah juga ikut berkontribusi pada nuansa perkembangan anak. Oleh sebab itu, baikburuknya struktur keluarga dan masyarakat sekitar akan sangat mempengaruhi baik atau buruknya pertumbuhan kepribadian anak. Lingkungan keluarga yang berkontribusi sebagai faktor penyebab kenakalan remaja misalnya, keluarga yang rusak, rumah tangga hancur yang disebabkan oleh kematian ayah atau ibunya, keluarga dalam konflik kekerasan, ekonomi keluarga miskin, semuanya merupakan sumber suburnya kenakalan remaja.

Kartini Kartono juga mengatakan bahwasannya faktor yang berkontribusi pada terjadinya kenakalan remaja meliputi: 1. Anak kurang mendapatkan perhatian, kasih sayang serta bimbingan dari orang tuanya, terutama bimbingan ayah, karena ayah dan ibunya lebih peduli dengan permasalahan serta konflik internal mereka sendiri; 2. Kebutuhan fisik maupun psikis anak-anak remaja yang tidak dapat dipenuhi, keinginan serta harapan remaja tidak dapat disalurkan dengan baik atau dikompensasi secara memuaskan; 3. Anak tidak pernah menerima pelatihan fisik dan mental yang amat diperlukan untuk kehidupan yang normal, mereka tidak biasa dengan disiplin serta pengendalian diri yang baik.

Oleh karena itu, perhatian dan kasih sayang orang tua dapat memengaruhi suasana hati seorang remaja ketika membentuk kepribadian dan sikap remaja sehari-hari mereka. Jadi salah satu faktor yang berkontribusi pada kenakalan remaja yaitu perhatian dan kasih sayang dari orang tua.

Kedua, Minimnya pemahaman tentang keagamaan. Dalam kehidupan berumahtangga, kurangnya pembinaan agama juga merupakan salahsatu faktor terjadinya kenakalan remaja. Agama memainkan peranan yang sangat penting dalam perkembangan moral, karena nilai-nilai moral yang berasal dari agama tetap tidak berubah oleh sebab berubahnya waktu dan tempat. Bimbingan moral atau agama bagi remaja melalui rumahtangga harus dilakukan sejak masa anakanak sesuai usia mereka, karena setiap anak yang dilahirkan tidak memahami apa yang benar dan apa yang salah, juga tidak memahami di mana batas peraturan moral berada dilingkungan mereka. Karena itu, kepemimpinan moral pada awalnya dilakukan di rumahtangga dengan pelatihan serta petunjuk-petunjuk yang dianggap baik. 
Maka bimbingan moral dari orang tua harus meneladani dan memberi contoh-contoh yang baik dalam bentuk hal-hal yang mengarah pada tindakan positif, karena apa yang dicapai oleh remaja dirumah tersebut akan dibawa ke dalam masyarakat. Oleh karena itu, pelatihan moral dan agama dalam keluarga sangat penting untuk melindungi remaja dari kejahatan dan merupakan cara mempersiapkan masa depan bagi generasi masa depan, karena kesalahan dalam pelatihan moral dapat berdampak negatif pada remaja.

Pemahaman tentang agama akan lebih baik jika ditanamkan semenjak dini, yaitu oleh kedua orang tua, memberikan bimbingan moral dan bimbingan tentang agama sehingga nanti, setelah mereka remaja, mereka dapat mengklasifikasikan antara perbuatan baik dan buruk yang ingin mereka perbuat setiap hari. Keadaan masyarakat saat ini, yang amat menjunjung tinggi ilmu pengetahuan telah menyebabkan norma-norma moral dan perilaku yang dipegang oleh orang terdahulu tertinggal. Dalam masyarakat yang terlalu jauh dari agama, kemerosotan moral orang dewasa tersebar luas. Kemerosotan moral, perilaku dan tindakan orang dewasa yang tidak baik menjadi panutan atau panutan bagi anak-anak dan remaja, sehingga berdampak kenakalan remaja.

Ketiga, Pengaruh dari lingkungan sekitar Pengaruh budaya Barat dan kontak dengan teman sebaya tidak jarang menyebabkan untuk mencoba hingga akhirnya jatuh ke dalamnya. Lingkungan sangat mempengaruhi perilaku dan karakter anak remaja. Jika dia hidup dan berkembang dalam lingkungan yang tidak baik, maka demikian juga moralnya akan seperti itu. Sebaliknya, jika dia dalam lingkungan yang baik tentu dia akan baik pula.

Dalam kehidupan sosial, remaja sering menimbulkan masalah dan mengganggu kedamaian masyarakat karena mereka dipengaruhi oleh budaya barat atau pergaulan rekan-rekan mereka, yang sering dipengaruhi oleh keinginan untuk mencoba. Seperti yang diketahui remaja umumnya dikenal sangat senang dengan sesuatu yang baru tanpa menyadari aspek negatifnya, karena jika tidak mengikutinya mereka dianggap ketinggalan zaman.

Keempat, Tempat pendidikan. Tempat pendidikan, dalam hal ini yang lebih spesifiknya adalah berupa lembaga pendidikan atau sekolah. Kenakalan remaja ini tidak jarang terjadi ketika anak berada dilingkungan sekolah dan jam pelajaran sedang kosong. Belakangan ini sering kita melihat di media-media telah terjadi kekerasan antar siswa di satu sekolah 
yang sama. Ini menjadi bukti bahwasanya lembaga pendidikan/sekolah juga memiliki andil terhadap kenakalan dan dekadensi moral yang terjadi di negeara ini. ${ }^{13}$

\section{Pengaruh Labelling Terhadap Kenakalan Remaja}

Teori penjulukan/labelling ini muncul pada akhir 1950-an dan awal 1960-an sebagai hasil dari studi mengenai penyimpangan perilaku dan sebuah penolakan terhadap teori konsensus atau teori struktur fungsional yang melihat penyimpangan sebagai perilaku berlebihan yang mengganggu norma-norma sosial dalam masyarakat. Menurut Edwin M. Lemert, seseorang melakukan suatu penyimpangan karena suatu proses labelling atau pemberian stigma, label, dan merek yang masyarakat berikan kepada individu. Awal mula seseorang berbuat suatu hal yang menyimpang, yang oleh Lemert disebut dengan penyimpangan primer (primary deviation). Seseorang mendapatkan cap/label sebagai pencuri, penipu, permerkosa, perempuan nakal dan sebagainya akibat dari melakukan penyimpanganpenyimpangan misalnya seperti pencurian, penipuan, pelanggaran susila dan lainnya. Maka, si pelaku penyimpangan primer kemudian memberikan definisi kepada dirinya sendiri sebagai penyimpang dan mengulangi penyimpanganya lagi kemudian melakukan penyimpangan sekunder (secondary deviation) sehingga mulai mengadopsi suatu gaya hidup menyimpang (deviant life style) yang menghasilkan suatu perilaku menyimpang sebagai reaksi terhadap pelabelan oleh orang lain. ${ }^{14}$

Teori penjulukan, secara sederhana, hanya menyatakan dua hal. Pertama, orang berperilaku normal atau tidak normal, tidak menyimpang atau menyimpang tergantung pada bagaimana orang lain menilai mereka. Penilaian ini sudah ditentukan oleh klasifikasi yang terhubung dengan pemikiran orang lain. Apa pun yang tidak dianggap masuk sebagai kategori yang baku oleh masyarakat (disebut residual) secara otomatis ditetapkan sebagai penyimpangan (seorang devians). Kedua, Kedua, dari waktu ke waktu penilaiannya berubah sehingga orang yang dinyatakan sakit hari ini dapat dinyatakan sehat (dengan gejala yang sama) beberapa tahun kemudian, atau sebaliknya. Jika seseorang diberi julukan yang mengarah pada kejahatan atau perilaku kriminal, orang itu dapat "berhati-hati" untuk melihat sisi negatifnya (seperti orang yang dicap nakal, kriminal, dan lain

${ }^{13}$ Dadan Sumara, Sahadi Humaedi \& Meilanny BudiartiSantoso, , hlm. 347-349

${ }^{14}$ Nazari Ayu, Khairulyadi, Op.cit, hlm. 235 
sebagainya). Teori penamaan/penjulukan lebih berfokus pada pemahaman kenakalan remaja, karena ini terjadi setiap kali remaja mencoba untuk membentuk identitas mereka. Calhoun menyatakan, teori penjulukan juga membantu dalam menjelaskan konsekuensi jangka panjang dalam pengaruh julukan sebagai deviasi pada identitas sosial seseorang. ${ }^{15}$

Pada perkembanganya muncul teori labelling formal dan informal. Labeling formal berlaku untuk individu yang telah melakukan kontak dengan lembaga formal baik berupa sistem pendidikan atau pemasyarakatan dengan wewenang untuk secara resmi memberi label individu (atau remaja) sebagai menyimpang. ${ }^{16}$ Karena tingginya tingkat residivisme, telah ada permulaan baru-baru ini dalam penelitian tentang efek kriminogen dari labelling formal. ${ }^{17}$ Kemudian ada juga informal labelling yakni label yang diterapkan kepada individu oleh seseorang yang tidak memiliki wewenang formal atau kecakapan professional untuk menelisik antara perilaku menyimpang dan perilaku tidak menyimpang.18 Orang tua adalah sumber utama label informal, dan label informal dapat memiliki pengaruh langsung pada konsep diri atau harga diri seseorang. Studi tentang konsep diri adalah bagian rumit dari penelitian teori pelabelan. Pada saat ini masyarakat dengan mudahnya memberikan label negatif terhadap orang lain bahkan terhadap remaja, tanpa memikirkan konsekuensi atas tindakan pelabelan tersebut. Remaja yang terlabel akan mengalami kehidupan sosial yang sulit, sehingga membuat remaja akan dengan mudahnya terjebak dan tidak mampu bangkit dari label negatif yang diberikan oleh masyarakat bahkan mengulangi perilaku menyimpang/nakalnya tersebut.

Labelling formal label resmi, seperti penangkapan resmi atau penuntutan, dapat memiliki implikasi dramatis yang mirip dengan "hambatan struktural". Bagaimanapun, bahkan meskipun beberapa individu tidak menerima label yang diterapkan secara formal, prosesnya ditangkap dan dituntut kemungkinan mengarah pada pengembangan label informal atau pelabelan diri negatif. Mengatasi hal ini mendukung hipotesis pelabelan ketika mereka menemukan bahwa kontak polisi yang dilaporkan sendiri,

15 Dadi Ahmadi, Aliyah Nur'aini H, hlm. 299

16 Chiricos,T., Barrick, K.,Bales, W., \& Bontrager, S, "The labeling of convicted felons and its consequences for recidivism". Criminology Vol. 45 No. 3 (Septeber 2007): hlm. 581.

17 Ibid, hlm 590

18 XiaoruLiu, "The conditional effect of peer groups on the relationship between parental labeling and youth delinquency". Sociological Prspectives Vol.43 No.3 (2000): hlm. 504. 
atau kenakalan resmi, terjadi hubungan positif yang signifikan dengan konsep diri nakal.

Efek penangkapan dan sanksi menunjukkan bahwa penangkapan dapat meningkatkan kenakalan di masa depan atau memiliki konsekuensi yang sangat kecil. Keterlibatan masa depan dalam kenakalan. Bahkan lebih baru-baru ini, ada minat yang dihidupkan kembali dalam memeriksa efek pelabelan pada hasil non-kriminal yang dapat mengintensifkan kenakalan. Mereka menemukan bahwa pelabelan formal, seperti intervensi polisi selama masa remaja, memiliki efek tidak langsung yang signifikan pada hasil pidana dan non-pidana di kemudian hari. Pelabelan formal, atau intervensi polisi, sangat berpengaruh pada hasil non-kriminal seperti pendidikan, pekerjaan, dan stabilitas keuangan. Hal ini sejalan dengan teori pelabelan.

Labelling informal sangat erat kaitanya dengan keluarga dari para remaja. Penelitian dari Sampson dan Laub menemukan bahwa label memiliki dampak negatif pada kejiwaan status pekerjaan pasien, persahabatan, tingkat pendapatan, dan bahkan hubungan keluarga. Kemudian penelitian tersebut mengemukakan bahwa teori pelabelan dimodifikasi dan direvisi untuk memeriksa kenakalan dan kejahatan, dan tidak hanya digunakan sebagai teori penyakit mental. Mereka menunjuk secara khusus pada peran yang dimainkan keluarga dalam kenakalan masa depan dan menyoroti bahwa interaksi sosial timbal balik dimulai di dalam keluarga. Mereka secara khusus menyatakan bahwa "mengasuh anak, setidaknya sebagian, adalah sebagai reaksi terhadap temperamen anak-anak, terutama yang sulit.

Menurut teori ini, proses pelabelan ini sangat kuat sehingga korban dari definisi yang salah ini mereka tidak dapat menahan pengaruhnya. Karena banjir julukan yang bertentangan dengan pandangan mereka sendiri, citra diri asli mereka menghilang dan digantikan oleh citra diri yang baru dari orang lain. Meskipun pada awalnya hal demikian bertentangan dengan keinginan mereka. Dampak julukan ini lebih serius, terutama terhadap orang-orang yang berada dalam posisi lemah. Atau bisa dikatakan, bahwa teori ini menyatakan bagaimana identitas diri dan perilaku dipengaruhi atau dihasilkan oleh sistem sosial. Ada pemikiran dasar dalam teori julukan yang mengatakan bahwa seseorang yang dipanggil seseorang yang devians dan mendapat perlakuan seperti seseorang yang devians bisa menjadi seorang devians. 
Dalam sosiologi dan kriminologi, Teori ini berfokus pada kecenderungan linguistik dimana mayoritas memiliki label negatif sebagai keadaan aktual atau merupakan penyimpangan dari norma, dan ini terkait dengan citra diri dan stereotip. Sebagai aplikasi fenomenologi, hipotesis teori ini mengatakan bahwa nama yang diberikan mempengaruhi perilakunya. Sebagian besar aplikasi ini memiliki nama negatif dan stigmatisasi (seperti kriminal), meningkatkan perilaku menyimpang dan menjadi konsep diri. Misalnya seperti, seseorang yang diberi label tidak memiliki peluang besar untuk memberi penjelasan mengenai arti sebenarnya dari pelabelan tersebut. Dari sudut pandang sosiologi, pelabelan memiliki keterkaitan pada seseorang yang dilabeli dengan diagnosis spesifik penyakit mental yang menyebabkan perilaku menyimpang. Sehingga, seterusnya orang ini akan mendapat perawatan medis sebagai orang yang "sakit mental".

Memberi label atau memberikan cap tertentu kepada seseorang atau sekelompok orang memiliki dampak besar pada kemungkinan terjadinya perilaku yang menyimpang. Sama seperti perilaku kenakalan salahsatu anak, yang masyarakat anggap sebagai anak yang bandel/nakal, itu karena pelabelan yang menyebabkan anak-anak mengembangkan perilaku nakalnya tersebut. Masyarakat akan memperlakukan anak-anak sesuai dengan stigma yang ada pada mereka. Ini menjadi siklus yang diulang dan semakin kuat. Stigmatisasi akan dilakukan oleh masyarakat jika anak tersebut memiliki latar belakang keluarga yang tidak harmonis dan lingkup pergaulan mereka dengan anak-anak yang menganggur dan menyimpang.

Dengan memberi label, anak tersebut diklasifikasikan oleh masyarakat sebagai anak yang buruk. Agar label tidak diberikan pada anak, maka anak tersebut harus memperbaiki tingkah lakunya menjadi lebih baik. Orang bersikap normal atau tidak normal, menyimpang atau tidak menyimpang, tergantung pada bagaimana persepsi orang lain (orangtua, keluarga dan masyrakat). Apabila seorang anak berbuat menyimpang, tidak jarang masyarakat segera menstigma anak tersebut sebagai anak yang nakal tanpa alasan yang jelas. Hal inilah yang membuat perilaku tersebut ke dalam perbuatan menyimpang semakin kuat, hingga kehidupan sehari-hari anak tersebut sangat dipengaruhi oleh pelabelan yang dimilikinya. Label sebagai perokok dan minum minuman keras membuat mereka menjadi ketergantungan pada rokok serta minum-minuman keras, karena mereka menganggap bahwa pelabelan yang diterimanya cenderung ke- 
pada keseluruhan kepribadianya bukan perilakunya satupersatu, sehingga dari label yang diterima tersebut membuat mereka memainkan peran seluruh kepribadiannya kearahnegatif. Padahal, tidak semua stigma buruk itu adalah kepribadian mereka yang sebenarnya. ${ }^{19}$

Dengan demikian dapat dilihat bahwa pelabelan atau pemberian stigma tertentu seperti anak nakal, pencuri, pemabuk, penjahat atau stigma lain yang negatif terhadap remaja dapat menjadi salah satu faktor yang sangat berpengaruh dalam kenakalan remaja.

\section{Simpulan}

Kenakalan remaja merupakan segala perbuatan yang meliputi tindakan menyimpang dari kaidah-kaidah hukum yang dilakukan oleh remaja. Yang mana terdapat dua faktor yang melatar bealakangi hal tersebut. Yaitu, faktor yang berasal dari eksternal dan faktor yang berasal dari internal. Dan faktor eksternal inilah yang lebih mendominasi jika dibandingkan dengan faktor internal. Adapun faktor eksternal yang muncul, yaitu kurangnya perhatian serta kasih sayang dari orang tua, kurangnya pemahaman tentang moral/keagamaan, pengaruh dari lingkungan sekitar, serta pengaruh lembaga pendidikan atau sekolah.

Terjadinya perilaku meyimpang dikalangan remaja sangat dipengaruhi oleh stigmatisasi atau pemberian label negatif tertentu dari seseorang atau kelompok masyarakat. Dalam sosiologi dan kriminologi dikatakan bahwa perilaku akan sangat dipengaruhi oleh label yang diberikan, kebanyakan penerapan ini memiliki label atau stigma ke arah yang negatif (seperti kriminal), meningkatkan perilaku yang menyimpang hingga menjadi suatu karakteristik diri seseorang. Seperti halnya anak yang sudah dianggap sebagai anak "nakal" oleh masyarakat, maka akibat dari pelabelan tersebut yang membuat anak akan terus mengembangkan perilaku menyimpangnya itu.

19 Tiara Farita Sari Nadeak, F.X. Sri Sadew, "Fenomena"Anak Nakal" DiRungkutSurabaya”. Paradigma,Vol. 2 No. 2 (Juli 2014): hlm. 5. 


\section{DAFTAR PUSTAKA}

Becker, H.S. Outsiders: Studies in thesociology of deviance. New York: Free Press. 1963.

Chiricos, T., Barrick, K., Bales, W., \& Bontrager, S. "The labeling of convicted felons and its consequences for recidivism". Criminology, Vol. 45 No. 3 Septeber 2007: 547-581.

Dewi, Yustika Tri, Budiarti S, Meilanny. Sahadi Humaedi \& Budhi Wibhawa. "Faktor Penyebab Tergabungnya Remaja Kota Bandung Dalam Komunitas Kenakalan Remeja". Share: SocialWork Jurnal Vol. 7 No. 1, Juli 2017: 13-20.

Hutagalung, Ali Akhbar Rafsanjani. "Kajian Kriminologis Perilaku Nakal Anak Jalanan (Studi Kasus Di Yayasan Setara Semarang)". Skripsi, Semarang: Program Sarjana Fakultas Hukum Universitas Negeri Semarang, 2017.

Iis Susanti, PambudiHandoyo. "Perilaku Menyimpang Di Kalangan Remaja Pada Masyarakat Karangmojo Plandaan Jombang". Paradigma Vol. 3 No. 2, 2015: 1-6.

Kartono, Kartini. Patologi Sosial 2: Kenakalan Anak. Jakarta: Raja Grafindo Persada. 2010.

Lestriono, Rudi. “Tinjauan Kriminologis Terhadap Kenakalan Remaja Di Kabupaten Luwu Timur". Skripsi, Makassar: Program Sarjana Fakultas Hukum Universitas Hasanuddin. 2013

Nashriana. Perlindungan HukumPidana Bagi Anak DiIndonesia. Jakarta: Rajawali Pers, 2012.

Nazari Ayu, Khairulyadi. "PengaruhStigma Terhadap PerubahanPerilaku Remaja (Studi Terhadap Stigma Negatif Remaja Mukim Kongsi Gampong Kuta Barat Kota Sabang)". Jurnal Ilmiah Mahasiswa Fisip Unsyiah Vol. 4 No. 1, Februari 2017: 232-243.

Rio Tutrianto, "Munculnya Wilayah Kejahatan di Perkotaan (Studi Pada Kota Pekanbaru)". Jurnal KriminologiIndonesia Vol. 14 No. 1, Mei 2018: 15-24.

Sampson, R. J., \& Laub, J. H, A life-course theory of cumulative disadvantage and thestability of delinquency. Developmental theories crime and delinquency edited by T. P. Thornberry (Eds), New Brunswick: NJ. Transaction. 1997. 
80 | Adliya: Jurnal Hukum dan Kemanusiaan, Vol. 14, No. 1, Juni 2020

Sumara, Dadan, Humaedi. Sahadi, \& Santoso, Meilanny Budiarti. "Kenakalan Remaja Dan Penanganannya". Jurnal Penelitian\&Ppm Vol. 4, No. 2, Juli 2017: 346-353.

Sunarto, Kamanto. Pengantar Sosiologi. Jakarta: Lembagapenerbit Fakultas Ekonomi UI, 2004

Tiara Farita Sari Nadeak, F. X. Sri Sadewo. "Fenomena"Anak Nakal" Di Rungkut-Surabaya". Paradigma Vol. 2 No. 2, 2014: 1-6.

Xiaoru Liu. "The conditional effect of peer groups on the relationship between parental labeling and youth delinquency". SociologicalPerspectives, Vol. 43 No. 3, Autumn, 2000: 499-514. 